\title{
Pandemic and the Emerging Threshold of Disaster Law in South Asia
}

\author{
Amita Singh \\ Former Professor, Centre for the Study of Law and Governance, Jawaharlal Nehru \\ University
}

\section{Staying Prepared as 'Biological Warfare' is unavoidable?}

An unprecedented biological warfare upon mankind from an unknown microbe of nature has shot down human arrogance notwithstanding its unbridled desire to conquer nature even if it is for an ephemeral moment. This arrogance to control nature has been built over years as science progressed from its invention of gunpowder around the $11^{\text {th }}$ century to the Alfred Noble's invention of dynamite in 1867. Currently, as we wade through the "Anthropocene"1 the robot armies managed from miles away through a remote button of Artificial Intelligence (AI) human life becomes increasingly vulnerable. Scientific and technological developments over centuries have been giving an illusion to mankind that man is a supreme being and in full command of nature whereas the pandemic has thrown off all such illusions of power to thin air and it's a pandemic which may not end, nor would end man's ambition to control nature. As epidemiologists have warned that the spell of death and destruction will be repeated as a large number of virology labs across the world have been working on lethal viruses ${ }^{2}$ ready to destroy mankind with deadlier microbial disasters as microbial research is one of the biggest businesses ${ }^{3}$ of today. However, mankind has to create a more robust system to prevent and to manage such a pandemic which is likely to become a feature of modern life.

This period has also exposed the lack of disaster preparedness of some of the most developed nations which are ironically, leaders in global virology research, and has

1 The term 'Anthropocene' was coined in 2000 by Nobel Laureate Paul Crutzen and Eugene Stoermer to denote the present geological time interval in which human activity has profoundly altered many conditions and processes on Earth.

2 Eduardo Baptista, Linda Lew, Simone McCarthy and Peter Langan, 'The Labs where monsters live' South China Morning Post (China, 12 September 2020) <https://multimedia.scmp.com/ infographics/news/world/article/3101114/biosafety-laboratories/index.html> accessed 26 April 2021. "As countries around the world invest in Biosafety Level 4 laboratories to study lethal viruses and prepare against unknown pathogens, some scientists are sounding the alarm about the potential for a catastrophic accident or attack."

3 Maria Poptsova, 'Market Analysis- Clinical Microbiology 2020' (2019) 10(6) Archives of Clinical Microbiology <https://www.acmicrob.com/microbiology/market-analysis-clinical-microbiology2020. pdf $>$ accessed 26 April 2021, 'Applied Microbiology size was valued at over USD 24.3 billion in 2017 and will exceed USD 675.2 billion with 7.9\% CAGR from 2017 to 2024. At Global Market Insights, It is a unique blend of primary and secondary research, with validation and iterations, in order to minimize deviation and present the most accurate analysis of the industry.' 
evoked consciousness amongst the not so developed towards neighbourhood collaborations, regional and multilateral agreements. These nations rich or poor, have demonstrated immense confusion, fuzziness and visible ignorance to laws on the subject, notwithstanding the warnings given by the Hyogo Framework for Action 2005-2015: Building the Resilience of Nations and Communities to Disasters (Paragraph 16), that nations need to develop policy legislative and institutional frameworks to track progress through measurable indicators.

Countries that develop policy legislative and institutional frameworks for disaster risk reduction and that are able to develop and track progress through specific and measurable indicators have greater capacity to manage risks and to achieve widespread consensus for, engagement in, and compliance with disaster risk reduction measures across all sectors of society.

However, deficits of information on the pathogenesis and prognosis of the microbe has kept on hold a matching legislative and institutional frameworks.

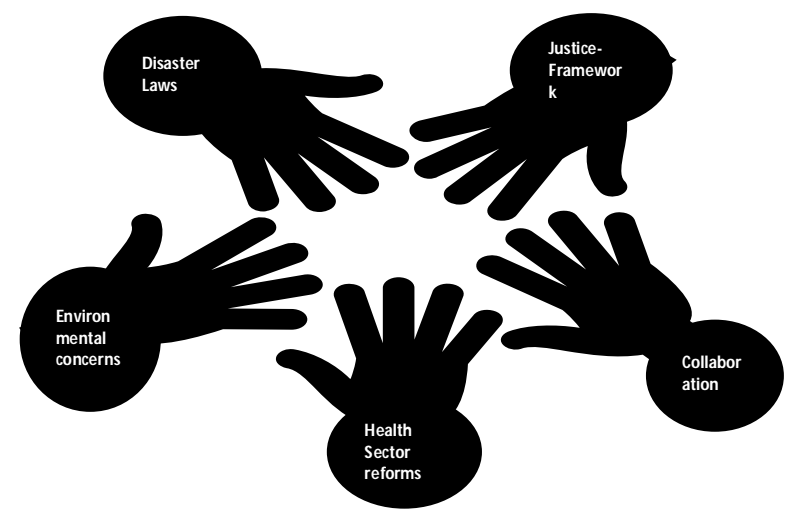

Fig: Covid-19 highlights five key opportunity areas for legal research

\section{Five takeaways from the current pandemic for staying prepared}

1. Update laws for disaster preparedness in the context of biological disasters. These disasters are quite different from other disasters in terms of their nature, impact and post disaster challenges. This would require a relook at country specific Disaster Management Acts and all regulations emerging from them.

2. Refine framework for substantive justice for victims of disasters. There are many types of victims of disasters: those who get infected, medical workers also known as frontline workers, burial workers and people and business centres affected by lockdowns.

3. Strengthening international and regional collaboration. The basic framework as set by the Hyogo Declaration and Sendai framework of Action carried forward through several regional efforts with the initiative of UNO and International Federation of Red Cross \& Red Crescent Societies are 
lighthouses in this direction.

4. Urgent need for an inclusive Health Sector Reforms. Covid-19 has exposed the fragility of big high class hospitals which had become a norm since the coming of globalization. Government based health care reforms, management of basic health infrastructure expenditure even in most developed countries which systematically ignored many experts' warnings ${ }^{4}$ and despite legislative measures a larger part of GDP of most countries was lost to health care costs.

5. Prioritizing environmental concerns of climate change which includes concerns for waste disposal, animal-meat-wet markets ${ }^{5}$, water bodies-forestland management. The pandemic apparently started from Wuhan wet market but there is still no law against them in the UN list.

\section{LAW AS LAG, CASE STUDY OF LAWS FOR PANDEMIC MANAGEMENT IN INDIA}

Even though South Asian countries are more or less moving together in the management of pandemic control in tandem with their legal frameworks for disaster management yet for a more appropriate clarity of data this paper will focus only on one country's case study. Biological disasters have not been uncommon in human history but were inadvertently left out in disaster management acts of most countries due to lack of experience about them in traditional literature of disaster management. India has been the first country in South Asia to bring about a Disaster Management Act in $2005^{6}$ (DMA2005) but the management of biological disasters came later in the 2008 National Disaster Management Guidelines of National Disaster Management Authority. Prior to the DMA2005, a 1999 document 'Report of the High Power Committee on Disaster Management'(RHPCDM) had formed a Sub-Group V on Biological Disasters which had alerted on the need for preparedness through research and infrastructural development against a microbial epidemic ${ }^{7}$.

4 Peter Zweifel, Friedrich Breyer and Mathias Kifmann, Health Economics (London: Springer 1997) 1. "Given continued growth, the entire GDP of many industrialized countries could be consumed by health care expenditure (HCE) before the end of the twenty-first century."

5 Dina Fine Maron, 'Wet markets' likely launched the coronavirus. Here's what you need to know.' (National Geographic, 15 April 2020) <https://www.nationalgeographic.com/animals/2020/04/ coronavirus-linked-to-chinese-wet-markets/> accessed on 26 April 2021.

6 Other countries in the region which have disaster management acts are Afghanistan, Bangladesh, Bhutan, Maldives, Nepal, Pakistan and Sri Lanka.

7 Government of India, "Disasters related to this sub-group are biological disasters and epidemics, pest attacks, cattle epidemics and food poisoning. Our response mechanism to diseases which are forgotten or considered as conquered as well as the vulnerability of the population even to infections which respond favourably to most of the widely available anti- microbial agents such as plague needs to be strengthened. We have virtually no infrastructure, tools or expertise to contain them. Handling exotic pathogens warrants suitable infrastructure, notably, high containment laboratories of bio-safety level 3 and 4; recruitment of highly committed, dedicated and trained professionals; continuous availability of diagnostic reagents; enhancement of skills at various echelons of health professionals in early identification of such infections, investigation of outbreaks and institution of specific control measures. The impact of Transboundary Animal Diseases (TAD) causes constant loss to livestock production directly but also inhibits investment in the stock of higher productive potential and production system.

Page | 154 
If laws facilitate just and inclusive disaster management, countries also need sophisticated science and advanced virology and microbial research labs to feed laws with full information on the pathogenesis of the virus. The behaviour of a clandestine microbe which defies standard locations or an epicentre of disaster considered as step one in disaster management becomes an absconding offender in conflict with the police. A microbe, which throws into irrelevance massive investments in GPS-earth sciences and meteorological technology over generations and catches top policy makers off guard, can further complicate threshold measurements in disaster management. Despite a need for a legal framework to handle such a disaster, there was none available in the whole of South Asia beyond a mere acknowledgement of its existence as a fashionable symptom of progressive law making. So, the Covid-19 pandemic consequently threw governments into a panic search for civil and criminal penal codes and even return to colonial laws despite their long forgotten disappearance and redundancy such as The Epidemic Diseases Act of 1897 which was found and invoked in India.

The impact of the pandemic has gone much beyond the devastating Indian Ocean Tsunami of 2004 and the Pacific Tsunami of Tōhoku 2011 in Japan. The magnificent global cities with most technologically advanced medical systems groaned under the spectre of dead bodies, most other less privileged poor countries which were condemned for poverty, homelessness and big population performed relatively much better (See Table 1). Mitigation became more a concern for the rich countries which had become absolutely cosmetic, where the old family members survived in nursing homes and food was mostly churned through wet markets and refrigerators. The mortality rate of the elderly in developed countries as given in Table 2 would shock anyone in the region of South Asia. The culture of parental care in old age and the stigma of not abandoning seniors in old age homes has kept mortality of seniors drastically low in South Asia as compared to the western countries. This cultural support to governments by default in containing the virus does not mean that the attention wasn't needed to prevent myths and rumours from spreading to harm anyone's security as people panic under lack of correct information. Perceiving many species as spreaders of the deadly epidemic people started killing the clueless bats, then they started abandoning their pets, some found it a good opportunity to get rid of their poor tenants or their rural labour triggering a mass out-migration from cities. Repeated Guidelines and clarifications were being released from the World Health Organization (WHO) under 'myth-busters' ${ }^{8}$. Within countries their national disaster management authorities, Medical research organizations and health directorates helped in updating people on corona related information. However, for lack of complete information there have been furious eruptions from the masses against lockdowns, quarantining, isolation, tests and vaccination. To spread out such an extensive framework of disaster

India is currently following the eradication program for rinderpest. Ministry of Agriculture, 'Report of High-Powered Committee on Disaster Management' (NIDM, October 2001) 85 <https://nidm.gov.in/pdf/pubs/hpc_report.pdf > accessed 27 April 2021.

8 WHO, 'Coronavirus disease (COVID-19) advice for the public: Mythbusters' (WHO, 26 March 2021) $<$ https://www.who.int/emergencies/diseases/novel-coronavirus-2019/advice-for-public > accessed on 01 April 2021. 
law which could capture the unresearched microbe from a lab and a wet market down to a legislature is a challenge that modern law makers are faced with. It's a full-fledged world war with no Treaty of Versailles ${ }^{9}$ to penalize the originator and bring peace on its conclusion.

Table 1: A Comparative progression of Covid-19 \& Performance towards containment

\begin{tabular}{|c|c|c|c|c|c|c|c|}
\hline \multirow{2}{*}{$\begin{array}{l}\text { Countries } \\
\text { Approx. } \\
\text { Population }\end{array}$} & \multicolumn{2}{|c|}{ Total Cases } & \multicolumn{2}{|c|}{ Total Deaths } & \multirow[t]{2}{*}{ Total tests } & \multirow{2}{*}{$\begin{array}{l}\text { Tests / } \\
\text { Million }\end{array}$} & \multirow{2}{*}{$\begin{array}{l}\text { Deaths } \\
\text { /million }\end{array}$} \\
\hline & $\begin{array}{l}\text { Early } \\
\text { March }\end{array}$ & $\begin{array}{l}\text { Early } \\
\text { June }\end{array}$ & $\begin{array}{l}\text { Early } \\
\text { March }\end{array}$ & $\begin{array}{l}\text { Early } \\
\text { June }\end{array}$ & & & \\
\hline $\begin{array}{l}\text { China } \\
1.4 \mathrm{~b}\end{array}$ & 82078 & 83064 & 3298 & 4634 & Xxxxx & Xxxxx & 3 \\
\hline $\begin{array}{l}\text { Italy } \\
60 \mathrm{~m}\end{array}$ & 80539 & 236,142 & 8165 & 34167 & $4,443,821$ & 73493 & 565 \\
\hline $\begin{array}{l}\text { USA } \\
340 \mathrm{~m}\end{array}$ & 68334 & $2,089,825$ & 991 & $1,16,035$ & $23,076,038$ & 69,737 & 351 \\
\hline $\begin{array}{l}\text { Spain } \\
47 \mathrm{~m}\end{array}$ & 56188 & 289,787 & 4089 & 27,136 & $4,465,338$ & 95,507 & 580 \\
\hline $\begin{array}{l}\text { Germany } \\
84 \mathrm{~m}\end{array}$ & 42,288 & 186,795 & 253 & 8851 & $4,694,147$ & 56,036 & 106 \\
\hline $\begin{array}{l}\text { Iran } \\
83 \mathrm{~m}\end{array}$ & 29,406 & 180,156 & 2234 & 8584 & $1,173,208$ & 13,978 & 102 \\
\hline $\begin{array}{l}\text { France } \\
65 \mathrm{~m}\end{array}$ & 28,786 & 155,561 & 1695 & 29,347 & $1,384,633$ & 21,215 & 450 \\
\hline $\begin{array}{l}\text { UK } \\
68 \mathrm{~m}\end{array}$ & 11,662 & 291,409 & 578 & 41,279 & $6,240,801$ & 91,956 & 608 \\
\hline \multicolumn{8}{|l|}{ ASIA } \\
\hline $\begin{array}{l}\text { S.Korea } \\
51 \mathrm{~m}\end{array}$ & 9332 & 12003 & 139 & 277 & $1,081,487$ & 21,095 & 5 \\
\hline $\begin{array}{l}\text { Japan } \\
127 \mathrm{~m}\end{array}$ & 1387 & 17,292 & 46 & 920 & 328,730 & 2599 & 7 \\
\hline
\end{tabular}

9 The Treaty of Versailles of 1919 brought an end to World War I. It codified peace terms between the Allies and Germany and by holding the latter responsible for starting this war imposed harsh penalties upon it. At an outbreak of the current pandemic, many countries felt the need for such penalties upon China, as it was discovered that Wuhan lab was where the microbe generated from. This led to investigations by international teams including the BBC after a surprise revelation was made on this channel by a lady scientist Prof Shi Zhengli from the Wuhan Institute of Virology (WIV). She is known as the China's Batwoman since she had found that the 2003 SARS virus originated from a species of bat in Yunnan caves. See John Sudworth, 'Covid: Wuhan scientist would 'welcome' visit probing lab leak theory' $B B C$ News (Yunnan, 21 December 2020) <https://www.bbc.com/ news/world-asia-china-55364445> accessed 04 January 2021.

Page | 156 
Pandemic and the Emerging Threshold of Disaster Law in South Asia

\begin{tabular}{|l|l|l|l|l|l|l|l|}
\hline $\begin{array}{l}\text { Thailand } \\
70 \mathrm{~m}\end{array}$ & 1136 & $\mathrm{Xx}$ & 5 & 58 & 468,175 & 6708 & 8 \\
\hline $\begin{array}{l}\text { Pakistan } \\
220 \mathrm{~m}\end{array}$ & 1057 & $1,25,933$ & 8 & 2463 & 809,169 & 3667 & 11 \\
\hline $\begin{array}{l}\text { Indonesia } \\
273 \mathrm{~m}\end{array}$ & 893 & 35,295 & 78 & $\mathrm{Xx}$ & 463,620 & 1696 & 7 \\
\hline $\begin{array}{l}\text { India } \\
1.3 \mathrm{~b} .\end{array}$ & 724 & $2,98,283$ & 17 & 8501 & $5,363,445$ & 3889 & 6 \\
\hline
\end{tabular}

Source: United Nations Geoscheme available at

https://www.worldometers.info/coronavirus/?\#news, accessed $5^{\text {th }}$ June 2020

Table 2: Ageing Population and Covid-19 Deaths

\begin{tabular}{|l|l|l|l|}
\hline S.NO & Countries & Ageing 60+ & death/m \\
\hline 1 & Japan & $28 \%$ & 7.29 \\
\hline 2 & Italy & $23 \%$ & 565.78 \\
\hline 3 & Germany & $21 \%$ & 105.78 \\
\hline 4 & France & $20 \%$ & 437.4 \\
\hline 5 & Sweden & $20 \%$ & 472.74 \\
\hline 6 & Spain & $19 \%$ & 580.78 \\
\hline 7 & UK & $18 \%$ & 620.84 \\
\hline 8 & Russia & $15 \%$ & 45.14 \\
\hline 9 & South Korea & $14 \%$ & 5.36 \\
\hline 10 & China & $11 \%$ & 3.33 \\
\hline 11 & Sri Lanka & $10 \%$ & 0.51 \\
\hline 12 & India & $6 \%$ & 6.28 \\
\hline 13 & Bangladesh & $5 \%$ & 6.5 \\
\hline 14 & Pakistan & $4 \%$ & 11.61 \\
\hline 15 & Saudi Arabia & $3 \%$ & 25.43 \\
\hline 16 & UAE & $1 \%$ & 29.7 \\
\hline & & & \\
\hline
\end{tabular}

Source: Singh in Malhotra,Fernando, Haran 2020

Data Source: data available at WHO sites and Statista, available at https://www.statista.com/statistics/1104709/coronavirus-deaths-worldwide-per-millioninhabitants/ and WHO websites

\section{A. Updating Understanding on Disasters}

Disaster Management Acts in most countries, need redefinition of the word 'disaster' 
in a manner which accommodates both ample comprehensiveness to include new biological and nuclear challenges and highlights culpability of decision makers as its cause especially in their failure to manage and maintain infrastructure that becomes a cause for disasters. Due to definitional clarity, disaster management agencies in most South Asian countries had primarily handed the responsibility of containing Covid-19 to health departments and the officials of disaster management came into action much later. The fuzziness of law delayed the processes of identification, coordination and then responding to the new challenges which came with it. When the pandemic provoked policy makers in India to seek a comprehensive legal framework on mitigating such a disaster, they sought recourse to Entry 23, Concurrent List of the Constitution, which mentioned "Social security and social insurance" and Entry 29, of the Concurrent List which mentioned "Prevention of the extension from one State to another of infectious or contagious diseases or pests affecting men, animals or plants," can also be used for specific law making. Let us take a look at the definition of 'disaster' as found in the Disaster Management Act 2005 of India which was one of the first legal documents on disaster management in the region, the other came from Sri Lanka following the 2004 Tsunami $^{10}$.

A catastrophe, mishap, calamity or grave occurrence in any area, arising from natural or man-made causes, or by accident or negligence which results in substantial loss of life or human suffering or damage to, and destruction of property, or damage to, or degradation of environment and is of such a nature or magnitude as to be beyond the coping capacity of the community of the affected area.

This definition is very difficult to apply to a microbial or biological disaster which is neither restricted by space nor by time. It is still debatable whether the pandemic source was Wuhan in China or Italy, a laboratory or a wet market, so the current pandemic has not only caused a grave human catastrophe but also a political calamity despite the seeming absence of damage to property and the environment. A decade later a 2011 document of the Ministry of Home Affairs, titled 'Disaster Management in India' where a disaster is defined to include ecosystems, " "catastrophic situation in which the normal pattern of life or eco-system has been disrupted and extra-ordinary emergency interventions are required to save and preserve lives and or the environment". It is ironical that NDMA which is the apex disaster Management Body directly under the Prime Minister was oblivious of its earlier reports which had ample indicators the need for preparedness against a possible biological microbial attack. Disaster Law encounters a methodological change since the loss and damage assessments may require new tools for finding out the impact of the pandemic on society and people.

\section{B. Sustaining Business during Lockdowns}

As firms and businesses shut down with lockdowns which are quite arbitrary as night

10 Pakistan came up with its Disaster Management Act in 2010, Bangladesh and Afghanistan in 2012, Bhutan in 2013 and Nepal in 2017.

Page $\mid 158$ 
curfew or 20-30 days' lockdown, country's business comes crashing down. The labour in cities cannot cope up with reduced or uncertain wages and most industries or MSMEs (Micro, Small and Medium Enterprises) for lack of backend supplies close down. Generally, in situations of disasters force majeure clause is invoked in agreements. The law that governs disaster management has been dismissive about this legal terminology and so it was invoked from a case to case basis during the pandemic times. The Government of India issued an Office Memorandum (OM)on $19^{\text {th }}$ Feb. $2020^{11}$ which was prior to an Official declaration of a pandemic and the lockdown, which said that 'the disruption of the supply chains due to spread of coronavirus in China or any other country should be considered as a case of natural calamity and "force majeure clause" may be invoked, wherever considered appropriate, following the due procedure..'. However, the events which unfolded during the pandemic neither committed the government to support the affected commerce and business nor obliged it to extend any help as the interpretation of force majeure was restricted as per the terms of the contract with many conditions for its application from case to case. Legal experts and business analysts have found that companies cannot take shelter under section 56 of the Contract Act and seek frustration of a contract to avoid their contractual obligations ${ }^{12}$. Such situations have been allowed to happen despite the OM issued in advance by the government only brings to surface the advisory nature of the $\mathrm{OM}$ which is not binding on either party. In reality it is nothing and defeats the very purpose of the DMA 2005. The OM reads, 'coronavirus should be considered as a case of natural calamity and force majeure may be invoked, wherever considered appropriate, following the due procedure... a force majeure clause does not excuse a party's non-performance entirely, but only suspends it for the duration of the force majeure. The firm has to give notice of force majeure as soon as it occurs and it cannot be claimed ex-post facto...If the performance in whole or in part or any obligation under the contract is prevented or delayed by any reason of force majeure for a period exceeding ninety days, either party may at its option terminate the contract without any financial repercussion on either side'. Since this is not implicitly a binding document, it does not hand hold business trapped in an uncertain disaster.

There is a government side of the story too which prefers an executive recourse instead of a judicial one to address a problem emerging during a pandemic. The problem is doubled by the fuzzy contours of force majeure which has not been defined in Indian statutes except its reference can be found in Section 32 and Section 56 of the Indian Contract Act, 1872 which can be revisited in the context of their applicability during the pandemic. The two sections are read as follows;

Section 32: Enforcement of contracts contingent on an event happening: Contingent contracts to do or nor to do anything in an uncertain future event happens, cannot be enforced by law unless and until that event has happened.

11 Ministry of Finance, 'Office Memorandum: Force Majeure Clause' (Government of India, 19 February 2020) <https://doe.gov.in/sites/default/files/Force\%20Majeure\%20Clause\%20-FMC.pdf> accessed 27 April 2021.

12 Mini Raman and Angelina Talukdar, 'No Entitlement For claiming Force Majeure Relief during Covid-19' (Lexorbis, 31 July 2020) <https://www.lexorbis.com/no-entitlement-for-claiming-forcemajeure-relief-during-covid-19/> accessed 27 April 2021. 
If the event becomes impossible, such contracts become void.( contingent contracts)

Section 56: A contract to do an act which, after the contract is made, becomes impossible or, by reason of some event which the promisor could not prevent, unlawful, becomes void when the act becomes impossible or unlawful.(Frustration of a contract).

An interpretation of whether any party be given relief under the force majeure clause has a high threshold extending from its language, putting in specific situations, timing of the disaster event and the nature of business itself. In some recent cases it has refused to do so even to grant an ad interim-injunction in favour of the petitioner ${ }^{13}$ as recently in the Bombay High Court of Standard Retail Pvt. Ltd. vs. M/s G.S. Global Corp \& Ors $^{14}$, Order dated April 8, 2020. The precedent as set in a previous case of Standard Retail Pvt. Ltd, in which the Court relying upon Section 56 of the Indian Contract Act, 1972 terminated its contract with M/s G.S. Global Corp \& Ors (Respondent 1) could not be accepted by the Court. According to the petitioner, the Government had declared COVID-19 a pandemic and as a result lockdown was declared, therefore the petitioner terminated the contract with the Respondent 1 as unenforceable on account of frustration, impossibility and impracticability ${ }^{15}$. The petitioner's claim that the contract was subject to force majeure clause and Arbitration in accordance with the laws of Korea/Singapore/London was rejected. The Disaster Management Acts across South Asian countries are in need of greater clarity on the Clause when contracting parties would be relieved from performing their respective obligations under the contract during the period that such force majeure situations like the current pandemic continue.

\section{Exodus of Migrant Labour}

The current pandemic has also witnessed a strange but massive panic exodus of rural migrants or city construction workers from major cities in India when lockdown was announced. The Covid-19 virus arrived as a city calamity but the manner in which the government handled it made it look as if the rural migrants were unwanted not just in cities but anywhere else too. They were neither given safe passage back home or assured of basic relief if they wished to stay back in cities. The Prime Minister made lockdown announcement barely giving a four hours' notice for a billion plus population on which they were to lose wages, jobs and food. The relief he promised was that they would not be charged any rent during the lockdown period but with no guarantees against being thrown out by landlords. The DMA 2005 was blank on encountering a situation which renders 240 million workers jobless in cities and the executive were left free to make ad hoc short-sighted unplanned announcements which only deepened crisis. There was no framework to synchronize relief with management.

13 Energy Watchdog v CERC (2017) 14 SCC 80: (2018) 1 SCC (Civ) 133.

14 Standard Retail Pvt. Ltd. v M/s G.S. Global Corp \& Ors (2020) Commercial Arbitration Petition(L) No. 404 of 2020.

15 Commercial Arbitration Tribunal(L) No. 404 of 2020 also available at Law Street India LSI-257-HC-2020 (BOM)

Page $\mid 160$ 
The trade unions instead of the executive announcements demanded four basic requirements to be fulfilled during such a pandemic ${ }^{16}$ :

- A cash transfer of Rs. 7500 (US\$ 99,5) to all households below the income tax level for April, May and June

- Wages for workers at medium, small and micro enterprises paid for the same months

- Universal food distribution to all working people for at least six months

- Safe journey for millions of migrant workers

The executive announcements, on the one hand, forced the landlords to push out tenants and on the other hand trapped most MSME (Micro, Small and Medium Enterprises) owners into an extremely difficult position of paying high salaries to their employees without their company making any business. DMA 2005 had no clue on how to incorporate the demands of labour laws especially in the MSMEs so that community resilience building by the government does not end up as a nightmare for enforcement agencies.

\section{Vulnerable People}

Covid-19 has substantially changed the world of labour and work. Within three months of the first lockdown unemployment rate shot up from $6.74 \%$ to $24 \%$ pushing more than 40 crore people into abject poverty ${ }^{17}$. It also alerted about a falling labour participation ratio which weakens resilience and prevents smooth return to prelockdown economy. Such a deep impact of unprecedented economic and social disruption has contracted economy as never before ${ }^{18}$. The ILO in its Report The International Labour Standards (ILS) and Covid-19 $9^{19}$ has reiterated a need for revisiting International labour standards in the context of threats to public health and livelihoods for a long term and sustainable well-being of people across the world. It

16،Unions call for non-cooperation against Modi government' (IndustriALL, 09 June 2020) <http://www.industriall-union.org/unions-call-for-non-cooperation-against-modi-government> accessed on 27 April 2021.

17 Yogima Seth Sharma, 'Unemployment rate in India at 24\% for week ended May 17: CMIE' The Economic Times (Mumbai, $\quad 19 \quad$ May 2020 ) $<$ https://economictimes.indiatimes.com/news/economy/indicators/unemployment-rate-in-india-at-24for-the-week-ended-may-17-cmie/articleshow/75821968.cms> accessed 27 April 2021.

${ }^{18}$ World Bank, Global Economic Prospects 2020 (Washinton DC: World Bank Group 2020) 'The baseline forecast envisions a 5.2 percent contraction in global GDP in 2020-the deepest global recession in eight decades, despite unprecedented policy support. Per capita incomes in the vast majority of EMDEs (Emerging Markets and Developing Economies) are expected to shrink this year'. See World Bank, 'COVID-19 to Plunge Global Economy into Worst Recession since World War II' (World Bank 08 June 2020) <https://www.worldbank.org/en/news/press-release/2020/06/08/covid-19-to-plungeglobal-economy-into-worst-recession-since-world-war-ii> accessed 27 April 2021. That would represent the deepest recession since the Second World War, with the largest fraction of economies experiencing declines in per capita output since 1870.'

19 ILO, 'ILO Standards and COVID-19 (coronavirus): FAQ' (International Labor Organization, 29 May 2020) <https://www.ilo.org/ wcmsp5/groups/public/---ed_norm/---normes/documents/ genericdocument/wcms_739937.pdf> accessed 27 April 2021. 
has brought out relevant sections which countries should incorporate in their Covid-19 management policies. It suggests a tripartite (government, employers and workers) resolution of pandemic related problems such as unemployment, disruption of business chains, productivity, labour health, insurance support, migration and availability of goods and services within the legal framework of ILO.

The DMA 2005 under Chapter II,Sec.12 and Sec.13 has indicated a grant of some relief to victims of disasters. Sec.12 recommended guidelines for the minimum standards of relief to be provided to persons affected by disaster which includes medical cover and restoration of means of livelihood., Sec.13 recommends relief in repayment of loans or for grant of fresh loans to the persons affected by disaster on such concessional terms as may be appropriate. Under these sections, government had announced relief but despite Sec.12 (ii) suggesting special provisions for widows, orphans and others in vulnerable populations such as disabled, children and old citizens received no attention. The Hindu pilgrimage of Vrindawan, which, as per the 2019 Sulabh International Report is home to more than ten thousand widows as per a 2019 report by an NGO called Sulabh International, starvation, disease and isolation affected them very severely ${ }^{20}$. An equitable distribution of food between oversupplied and undersupplied regions has always been a challenge for governance in India despite her food surplus. The Global Hunger Index ranked India at 102 out of 117 countries in 2019 which became worse in 2020 as people lost jobs and rural wages dropped due to urban workers returning to their villages during lockdowns ${ }^{21}$. There are findings on how child trafficking $^{22}$ and violence against women increased manifold during covid-19. UN Women in its finding has called this increase in violence as "The Shadow Pandemic ${ }^{23}$ which needs collective efforts nay almost a movement for its prevention. These vulnerable groups of people found their welfare funds diverted to bring Covid relief notwithstanding an intensification of their problems during the same period.

\section{DRACONIAN LAWS TO FILL THE LAG}

Covid-19 has seen an imposition of draconian laws across many countries to enforce pandemic control measures. Implementing agencies which could not understand most medico-legal terminologies were posted in enforcement teams. As a consequence measures related to many situations in Covid-care were arbitrary due to confusions between policies of prognosis and pathogenesis in Covid-care, between quarantine and

20 Yogesh Bhardwaj, 'In Vrindavan, A Home for Widows Prepares to Protect Its Elderly From COVID19' (IndiaSpend, 04 April 2020) <https://www.indiaspend.com/in-vrindavan-a-home-for-widowsprepares-to-protect-its-elderly-from-covid-19/> accessed 27 April 2021.

21 Murali Krishnan, 'Coronavirus exacerbates India's Hunger Problem' ( $D W, 16$ October 2020) $<$ https://www.dw.com/en/coronavirus-exacerbates-indias-hunger-problem/a-55299109> accessed on 01 April 2021.

22 Joseph Wesley, 'How COVID-19 is exposing children to traffickers' Down to Earth (New Delhi, 04 December 2020) <https://www.downtoearth.org.in/blog/governance/how-covid-19-is-exposingchildren-to-traffickers-74525> accessed on 27 April 2021.

23 UN Women, 'The Shadow Pandemic: Violence against women during Covid-19' <https://www.unwomen.org/en/news/in-focus/in-focus-gender-equality-in-covid-19response/violence-against-women-during-covid-19> accessed on 27 April 2021.

Page | 162 
isolation and between social distancing and physical distancing ${ }^{24}$. These harsh measures that the government enforced ${ }^{25}$ led to a belief that covid-19 means death and people started abandoning even the dead bodies of Covid patients and also stopped entry of frontline Covid care doctors to their apartments. People felt that the government had not done its homework ${ }^{26}$ appropriately prior to its recourse to such harsh measures.

\section{A. Enforcement dilemmas}

In the absence of any required training or laws on the nature of epidemic, thermal screening at airports started by mid- January for passengers coming from China but later the list started becoming longer as Thailand, Singapore, Hong Kong, Japan and South Korea were added to it. Problems started soaring due to non-availability of a comprehensive nationwide surveillance system, testing infrastructure and public awareness. Most governments were free to apply laws the way it suited them. There was panic and overreaction at the level of ill-informed local administration encouraging them to use stringent measures for a larger mission driven control of pandemic which seemed like a 'foreign imported death' to one's country. This led to stigmatization and ostracization of human beings, racial profiling of certain religious groups and nationalities leading to violence and hate against foreigners ${ }^{27}$. It was unfortunate that a time when compassion and care should have guided thoughts and actions, debauchery and impiety became lighthouses for official action. This gross psychology only proved counterproductive to the spirit of preventive regulations. There followed more defiance to law which was perceived to be racially motivated in

24 Amita Singh, 'Covid-19 Pandemic and the Future of SDGs' in V.K. Malhotra, R.L.S. Fernando and N.P. Haran (eds), Disaster Management for 2030 Agenda of the SDG (Springer 2020) 313. 'Lack of training led to many avoidable problems in the implementation of a biological disaster. Most frontline workers, policemen and district officials did not have any idea on the history of epidemics or how nations have previously handled it or even the fact that there were guidelines which could save people from the worst.....Doctors and Nurses were not allowed entry into their apartment areas by the Resident Welfare Associations, bats were slaughtered, dogs and cats were killed and abandoned, a Covid-19 patient was stigmatized for being a cause for further spread of virus ...... the 'spirit' of law was violated due to the inexperience of authorities and also under the subtle and inscrutable influence of caste, class, gender and religion upon district authorities and the police'.

WE. Parmet 'Quarantining the law of quarantine: why quarantine law does not reflect contemporary constitutional law' (2018) 9(1) Wake Forest Journal of Law and Policy 1-33.

26 Singh, mentions the case of two doctors Ai Fen and Li Wenliang who were reprimanded for raising an alarm about a 'Sars Coronavirus which they had detected on $30^{\text {th }}$ December. P.313. Also read Monica Rull, 'The Ebola Wake-up call: The System's failings in Responding to Outbreaks' and Monica Rull, Ilona Kickbusch and Helen Lauer, 'International Responses to Global Epidemics: Ebola and Beyond' (2015) 6(2) International Development Policy | Revue internationale de politique de développement [Online] <http://journals.openedition.org/poldev/2178> accessed 27 April 2021. Also see Debora Mackenzie, 'We were warned -so why couldn't we prevent the coronavirus outbreak?" (NewScientist, 04 March 2020) <https://www.newscientist.com/article/mg24532724-700-we-werewarned-so-why-couldnt-we-prevent-the-coronavirus-outbreak/> accessed 27 April 2021.

27 "Covid-19 is not just a health issue; it can also be a virus that exacerbates xenophobia, hate and exclusion," said Fernand de Varennes, the UN Special Rapporteur on minority issues. See 'COVID19 stoking xenophobia, hate and exclusion, minority rights expert warns' (UN News, 30 March 2020) <https://news.un.org/en/story/2020/03/1060602> accessed on 27 April 2021. 
a political environment which appeared opaque and lacked trust in governance ${ }^{28}$. It also brought minorities to cling together in these unprecedented times when political leaders roamed free for electioneering ${ }^{29}$ and other political meetings but poor and peacefully protesting citizens were booked for not following the Covid-19 regulations.

Coercive, discretionary and sectional implementation does not spring from the Cabinet Secretary's enforcement of Section 2(d) of the Disaster Management Act 2005 but from the Section 2A of the Epidemic Disease Act (EDA) of 1897. The disaster management bureaucracy could conceal its culpability to a great negligence and further create much fear by imposing a 123-year-old draconian Epidemic Disease Act (EDA) of 1897 invoked for the first time in 1897 to prevent the spread of Bubonic Plague. This law was brought back to strengthen the hands of central government by legitimately transcending ordinary provisions of the law on the pretext that they were insufficient to prevent the spread of the disease. This law gave extraordinary powers to the central government to inspect, detain and punish people, ships and vessels (2A) where disobedience to any regulation or order made under the EDA shall be deemed to have committed an offence punishable under section 188 of the Indian Penal Code (45 of 1860) (Sec.3). Still, Section (4) comes like a protective sheath for administration assuring that "no suit or legal proceedings shall lie against any person for anything done is good faith intended to be done under the Act. Thereafter administration attributes to itself despotic power as civil liberties are suspended to contain the epidemic'. Studies have found that coercive measures may look like a fast pace achievement of overcoming the pandemic but they are primarily responsible for spreading the epidemic. A democratic society with a free flow of information ${ }^{30}$ is best suited to control the source of a pandemic. By relying on coercive draconian laws the bureaucracy for disaster management could divert attention from its own ineptitude on advance preparations in health sector reforms as given in the 1999 RHPCDM and 2011 document of the Ministry of Home Affairs, titled 'Disaster Management in India'. This led to an enormous slippage of the framework of substantive justice during the

${ }^{28}$ The Shaheen Bagh protests over the Citizen Amendment Bill and Tablighi Jamaat celebrations at the Nizamuddin Dargah Markaz occurred during the lockdown despite tough regulations in force. What followed was a massive manhunt for participants in these events who for fear of arrest hid around the country at undiscoverable destinations. See Abhishek Bhalla, 'Tablighi Jamaat coronavirus patient's Shaheen Bagh visit under scanner as contact tracing gets underway' (India Today, 02 April 2020) $<$ https://www.indiatoday.in/india/story/tablighi-jamat-coroanvirus-patient-s-shaheen-bagh-visitunder-scanner-as-contact-tracing-gets-underway-1662509-2020-04-02> accessed on 27 April 2021. Also read Sunil Rahar Report 'Covid norms go for a toss during political gatherings in Baroda' Hindustan Times (New Delhi, 25 October 2020) < https://www.hindustantimes.com/cities/covidnorms-go-for-a-toss-during-political-gatherings-in-baroda/storyTwqApRpKH7N51rWf4yHubK.html> accessed on 27 April 2021.

${ }^{29} \mathrm{C}$ K Manoj, 'No distancing, masks at Bihar poll rallies: Experts warn of spike in COVID-19 cases Health experts warn of rallies turning into 'super-spreader' events' (Down to Earth, 19 October 2020) <https://www.downtoearth.org.in/news/health/no-distancing-masks-at-bihar-poll-ralliesexperts-warn-of-spike-in-covid-19-cases-73854> accessed 27 April 2021.

30 Mathew M. Kavanagh, "Transparency and Testing Work Better Than Coercion in Coronavirus Battle" (Foreign Policy, 16 March 2020) <https://foreignpolicy.com/2020/03/16/coronavirus-what-workstransparency-testing-coercion/> accessed 27 April 2021.

Page | 164 
pandemic as given in the Constitution of India and read with the Disaster Management Act 2005.

\section{B. People Ignored by Law}

A large number of people got ignored by law during the pandemic i.e.; those in prisons, immigration detention facilities, refugee camps and psychiatric care centres. A UN Subcommittee on Prevention of Torture (SPT) which was created in 2007 for monitoring and advising governments to prevent torture and ill-treatment in places of detention issued an advice to prevent inhuman behaviour against those in detention during the pandemic. Of the total 90 states only 3 from South Asia (Afghanistan, Maldives \& Sri Lanka) have so far ratified this advice. Sir Malcolm Evans, the Chairman of this Committee said, 'Governments have to take precautionary measures necessary to prevent the spread of infection, and to implement emergency measures in ensuring that detainees have access to appropriate levels of health care and to maintain contact with families and the outside world..... ${ }^{31}$.Further he issued a statement from the SPT as 'an advice to state parties and national preventive mechanisms relating to the coronavirus disease (COVID-19) pandemic'. It has a preventive mandate focused on an innovative, sustained and proactive approach to the prevention of torture and ill treatment.

\section{Ostracization and Civil Liberties}

Such coercive laws that subjugate civil liberties through harsh applications of medical tools such as quarantines and isolation have been coming from old law books written on narratives from the ghastly and agonizing Bubonic Plague or 'black death' of the $17^{\text {th }}$ century London and the Spanish Flu of 1919. The Spanish Flu infected one third of the world population and killed more than $50 \mathrm{~m}$ of them. These narratives used old tools of governance since a behavioural understanding of science and its impact upon human mind and disease control had not yet arrived in medical and legal research ${ }^{32}$. As Gostin and Hodge (2020) comment on the use of old enforcement measures as of limited utility and if imposed with too heavy a hand, or too haphazard a manner, they can be counterproductive. Courts have also intervened to disallow such a harsh use of quarantines and isolation. This came up in a few old cases during the bubonic plague of 1900 ie; of Wong Wai v.Williamson and Jew Ho v.Williamson in the Federal Circuit Court for the Northern District of California at San Francisco's Chinatown. The plaintiffs stood against the Surgeon General of the United States who had ordered health authorities to implement 'extraordinarily coercive measures' aimed at city's Asian inhabitants, and this action led to ostracization of Asians in an American community. The verdicts coming out of these cases launched a new discourse in

31 'International Day in Support of Victims of Torture: detainees need protection from Covid-19' (Council of Europe, 26 June 2020) <https://www.coe.int/en/web/portal/-/international-day-in-supportof-victims-of-torture-detainees-need-protection-from-covid-19> accessed 27 April 2021.

32 L.O. Gostin and JG Hodge, 'US Emergency Legal Responses to Novel Coronavirus: Balancing Public Health and Civil Liberties' (2020) 323(12) JAMA - Journal of the American Medical Association 1131-1132. 
medico-legal policies which highlights court's innate capacity to act as an arbiter between the rights of an ostracized minority and public interest during periods of epidemics when governments use extraordinary coercive measures to address health emergencies $^{33}$. The court prevented the use of racially motivated emergency measures by the Surgeon General.

\section{PANDEMIC CONTROL REQUIRES SINCERE REGIONAL COLLABORATION}

South Asia is not just home to one-fourth of the world's population but $48 \%$ of the world's multi- dimensional poor as well ${ }^{34}$. It barely occupies $3.5 \%$ of world's land area and generates $3.6 \%$ GDP per annum. The region's rich biodiversity demands conservation and environmental safety for a healthy society. As per the SACEP Report (2016) South Asia is home to approximately 15.5 and 12 percent of the world's flora and fauna respectively ${ }^{35}$. The faunal diversity of the region comprises of 933 species of mammals, 4,494 birds, 923 reptiles, 332 amphibians and 342 freshwater fishes. The floral diversity accounts for 39,875 species of flowering plants, 66 conifers and cycads, 764 ferns and 6,652 higher plants ${ }^{36}$. Such bountiful natural resources over a single topographical plate have great potential for cooperation and collaboration for sustainable development policies. However, the region is predominantly a flood affected area and has the largest concentration (approx.40\%) of world's poor and vulnerable living and practising agriculture around these transboundary river basins ${ }^{37}$.The Ganges-Brahmaputra-Meghna river basin which equally affects Bangladesh, Bhutan, Nepal and India is the biggest of all ${ }^{38}$. It's called a 'hot spot' of Asia Pacific disaster zones. The GDP of this region is directly proportional to the many disasters they face many times in a year.

Disasters in South Asia are repeated encounters with hydro-meteorological and geological hazards such as floods, landslides, droughts, cyclones, earthquakes, heat waves, avalanches and tsunamis. Every year for the last many decades the low-lying countries like India and Bangladesh complain that the higher countries like Nepal and China flush out water to drown low lying regions. These seasonally flooded areas include Assam and surrounding sanctuaries and islands in the Sundarbans, the world's

33 Charles McClain, 'Of Medicine, Race, and American Law: The Bubonic Plague Outbreak of 1900’ (1988) 13(3) Law \& Social Inquiry 447-513.

34 Sabina Alkire and Gisela Robles, 'Global Multidimensional Poverty Index 2017' (2017) OPHI Briefing $47<$ https://ophi.org.uk/global-multidimensional-poverty-index-2017/> accessed 27 April 2021.

${ }^{35}$ SACEP, 'Milestones' <http://www.sacep.org/milestones> accessed on 27 April 2021.

36 SACEP, 'South Asia's Biodiversity: Status, Trend and Challenges' (South Asia Co-operative Environment Programme, December 2016) 1 <http://www.sacep.org/pdf/new-publication/SouthAsia-Biodiversity-Status-Trend-and-Challenges.pdf > accessed on 27 April 2021.

${ }^{37}$ World Bank, 'South Asia Water Initiative: Annual Report from the World Bank to Trust Fund Donors - July 2014-June 2015' (2016) World Bank Working Paper Report No. 103878 <http://documents1.worldbank.org/curated/en/442761468197632182/pdf/103878-AR-SAWI-

Progress-Report-2015-PUBLIC.pdf> accessed 27 April 2021.

${ }^{38}$ Marufa Akter, 'Conceptualizing environmental governance on the GBM basin' (2016) 3(1) Bandung: Journal of the Global South 25.

Page | 166 
largest mangrove forest straddling Bangladesh and India. The flooding of Kurigram in Bangladesh and Supaul in Bihar are classic examples of the need for collaborative law framework for addressing disasters in South Asia. Within the region Koshi flooding in South Asia (2008), Kashmir earthquake (2005), Indian Ocean Tsunami (2004), and recurrent tropical cyclones in Bangladesh and India. The tropical storm Aila on 2009 gripped India and Bangladesh over the Sundarbans island and their frontiers were obliterated.

It was only in the 3rd SAARC Summit when a comprehensive Regional Study on the Causes and Consequences of Natural Disasters was discussed for the first time. A SAARC Meteorological Research Centre was established in Dhaka in 1995 and a SAARC Coastal Zone Management Centre was set up at Male in 2004. Later in June 2005 a Special Session of the SAARC Environment Ministers adopted the Male Declaration, which called for formulation of a Comprehensive Framework of Disaster Management in South Asia. Yet it was only in the 13th SAARC Summit at Dhaka in November 2005 which considered the issues of regional cooperation for preparedness and mitigation of national disasters and set up a SAARC Disaster Management Centre (SDMC) in New Delhi in 2006. The Scope of the centre is expanded by merging the other Regional erstwhile centres of Bangladesh, Bhutan, Maldives with SDMC.

The recent pandemic has brought out a need for a common disaster law framework for South Asia which may be challenging enough considering many unresolved border issues amongst them. Climate change and global warming is leading to a steady sea level rise which is marooning many land areas and also eroding many islands. Consistent changes in ambient temperature and rainfall patterns combined with increase in cyclonic activity has affected all countries of the region equally. The coming of the pandemic pulls in stronger and more urgent reasons to explore and strengthen a common disaster law framework to encourage smooth collaboration for disaster mitigation and prevention.

Regional cooperation was initially spearheaded by the South Asian Association for Regional Cooperation (SAARC) which was formed in 1985 at Dhaka, Bangladesh, with the main objective; 'to promote welfare of people of South Asia, accelerate economic growth and increase collaboration and mutual assistance in economic, social, culture, technology and scientific fields ${ }^{39}$.There was no mention of either environmental protection or of disaster management but these requirements got added up as realization dawned that development and economic progress has close interdependence like Siamese twins with the former.The pandemic has strengthened a logic for environmental action alongside disaster response for each member state.

In this context it would be important to focus on Multiple Mortality Risk Index (MMRI) besides the co-morbidity concerns which caused more deaths due to corona virus infection. This multi-dimensional and a more holistic index makes a justifiable assessment of vulnerability in South Asian countries. UNESCO describes Mortality

${ }^{39}$ SAARC Charter, Objectives Art.1 <https://www.saarc-sec.org/index.php/about-saarc/saarc-charter> accessed on 02 April 2021. 
Risk Index (MRI) as, 'a Category of disaster risk based on both expected average killed per year and expected average killed per million people per year'. A UNESCO report further clarifies that this indicator considers hazard (intensity, frequency), population exposure and vulnerability for identifying vulnerability based upon MMRI ${ }^{40}$. MRI is a revised version of Disaster Risk Index (DRI) which is traditionally used to assess a country's vulnerability to disasters. Lately due to awakened sensitivity towards achievement of the Millennium Development Goals (MDGs, 2000-2015) and now the Sustainable Development Goals (SDGs, 2015-2030) other factors such as governance, nature of developmental policies, political instability and border management are added to mortality risk for the assessment of vulnerability. This is referred to as MMRI and is increasingly being used in contemporary studies on disasters. In one such study ${ }^{41}$ it was found that even though India had almost a six times higher rate of disasters as compared to Bangladesh and Pakistan nevertheless Bangladesh tops the list on the MMRI assessment. The three countries India, Bangladesh and Pakistan have highest MMRI as compared to others in the region and have urgent reasons to cooperate in disaster management.

This realization about vulnerability connect with the GDP led to a SAARC Joint Communique of 12 Jan 2010 which emphasized, 'work together in making SAARC a purposeful organization'. Since then, many efforts at more substantive collaborations have taken place within and outside the SAARC framework. In 2002, Bangladesh, Bhutan, India, Maldives, Myanmar, Nepal, and Sri Lanka formed South Asia Subregional Economic Cooperation program (SASEC) to promote regional prosperity, economic opportunities and boost intra-regional trade and cooperation in South Asia. Further, South Asian Free Trade Agreement (SAFTA, 2006) which appears to be by far the greatest achiever for collaboration in the region as it has been able to reduce customs duties on all traded goods from $20 \%$ to zero by 2012. Latest (Oct.2020) Hindu Kush Agreement effort of eight countries (Afghanistan, Myanmar, Pakistan, India, China, Nepal, Bhutan, Bangladesh) of the Hindu Kush Himalaya (HKH) region, is to control disasters over one of the world's greatest mountain systems. Efforts such as these also empower the implementation of many other disaster management efforts in the region. Most of these countries are also signatories of the Sendai Framework for Disaster Risk Reduction 2015-2030 which outlines four priorities for action to prevent disasters, i.e.;

(ii) Strengthening disaster risk governance to manage disaster risk

(iii) Investing in disaster reduction for resilience and

40 World Water Assessment Programme, 2006, UN World Water Development Report 2: Water: A Shared Responsibility; Paris, UNESCO and New York, Berghahn Books, p. 352 available at http://www.unesco.org/new/fileadmin/MULTIMEDIA/HQ/SC/pdf/wwap_WWDR2_Box_10.4.pdf accessed on March 8, 2021.

${ }^{41}$ SK Kafle, 'Disaster Risk Management Systems in South Asia: Natural Hazards, Vulnerability, Disaster Risk and Legislative and Institutional Frameworks' (2017) 7(3) Journal of Geography and Natural Disasters 5.

Page $\mid 168$ 
(iv) Enhancing disaster preparedness for effective response, and to "Build Back Better" in recovery, rehabilitation and reconstruction.

Much depends upon the ability and initiatives of the SAARC Disaster Management Centre to help incorporate the above priorities in the disaster management frameworks of SAARC member countries. In 2011, SAARC countries signed one of the most appropriate and focused agreement on improving disaster management in the region. It was titled, 'SAARC Agreement on Rapid Response to Natural Disasters' (SAARND). Its purpose was to professionalize disaster management system and strengthen emergency response system in the region, provide timely relief and humanitarian assistance in emergencies arising out of natural disasters and about institutionalizing disaster response in the region. An important point highlighted in this agreement made it incumbent upon member states to 'take legislative, administrative and other measures as necessary to implement their obligations under this agreement within the framework of the legal system prevailing in the respective member states.' Ironically, even though it succeeded in at least one initiative of creating a Food Bank for help during disasters and collected 4,86000 million tonnes of grains, the effort stagnated and disappeared soon. One is hopeful that with the recent revival of the Bay of the Bengal Multi-Sectoral Technical and Economic Cooperation (BIMSTEC) in which Bangladesh, India and Sri Lanka join hands with the two countries of SouthEast Asia (Myanmar and Thailand) may generate a more progressive and versatile groundwork for knowledge sharing and cooperation in the region.

\section{CONCLUSION}

The paper refers to many new challenges which are being faced by countries across the world and specifically those of South Asia. Due to clarity of analysis India's handling of the pandemic through its legal and executive framework has been undertaken as a case study with lessons for the countries in the region. The pandemic management raises many concerns of law and governance besides exposing a mismatch which exists between the disaster management acts of most countries and the rapidly changing requirements of pandemic management. The law is not adequately prepared to encounter an epidemic and it appears that to enforce disaster management laws governments have been exploring stringent outdated laws such as India's implementation of the Epidemic Disease Act 1897. Experts who have analysed epidemic control measures of governments since the 1900 bubonic plague have suggested against their usage or it would prove counterproductive in preventing the disease. In the end the paper suggests an effective regional collaboration for sharing information, medical support and scientific research to address biological disasters. This can be done by strengthening the SAARC and also to implement SAARND Agreement.

\section{References}

Bhalla, Abhishek, "Tablighi Jamaat coronavirus patient's Shaheen Bagh visit under scanner as contact tracing gets underway", India Today, April 2, 2020, 21:28 https://www.indiatoday.in/india/story/tablighi-jamat-coroanvirus-patient-s-shaheen-bagh- 
visit-under-scanner-as-contact-tracing-gets-underway-1662509-2020-04-02 accessed on Jan. 3, 2021.

Singh, Amita., "Covid-19 Pandemic and the Future of SDGs", in V.K. Malhotra, R.L.S.Fernando, N.P.Haran (eds), Disaster Management for 2030 Agenda of the SDG. Disaster Research and Management Series on the Global South. Singapore, Palgrave Macmillan, 2020

Manoj, C.K. "No distancing, masks at Bihar poll rallies: Experts warn of spike in COVID-19 cases Health experts warn of rallies turning into 'super-spreader' events", Down to Earth, October 19, $2020<$ https://www.downtoearth.org.in/news/health/no-distancing-masks-atbihar-poll-rallies-experts-warn-of-spike-in-covid-19-cases-73854> accessed on Jan.3,2021.

Sharma, Yogima Seth, "Unemployment Rate in India at 24\% for Week ended May 17: CMIE" $\begin{array}{llll}\text { The } & \text { Economic } & \text { Times, } & \text { May }\end{array}$ https://economictimes.indiatimes.com/news/economy/indicators/unemployment-rate-inindia-at-24-for-the-week-ended-may-17-

cmie/articleshow/75821968.cms?utm_source=contentofinterest\&utm_medium=text\&utm _campaign=cppst, accessed on Oct.3, 2020

Baptista, Eduardo., Lew, Linda., McCarthy, Simone ., Langan, Peter ., "Labs where monsters live", South China Morning Post, Sept.12,2020, https://multimedia.scmp.com/infographics/ news/world/article/3101114/biosafetylaboratories/index.html, accessed on Jan, 8, 2020

Varennes, Fernand de., "Covid-19 stoking xenophobia, hate and exclusion, minority rights expert warns", UN News, https://news.un.org/en/story/2020/03/1060602, accessed on Jan. 4, 2021.

Government of India, "Report of the High Power Committee on Disaster Management (HPCDM) Sub-Group V on Biological Disasters" , NDMA, Ministry of Home Affairs, India, 1999

Sudworth, John., "Covid: Wuhan scientist would 'welcome' visit probing lab leak theory”, BBC News, Yunnan, December 21 2020, https://www.bbc.com/news/world-asia-china55364445, accessed Jan 4, 2020

Wesley, Joseph., "How COVID-19 is exposing children to traffickers", Down to Earth, December 4, 2020. https://www.downtoearth.org.in/blog/governance/how-covid-19-isexposing-children-to-traffickers-74525, accessed Jan 3, 2021.

Gostin, L.O., Hodge, J.G., "US Emergency Legal Responses to Novel Coronavirus: Balancing Public Health and Civil Liberties". JAMA - Journal of the American Medical Association, Vol. 323, No. 12. 2020, pp. 1131-1132.

Mackenzie, Debora, "We were warned -so why couldn't we prevent the coronavirus outbreak?, Health Analysis", NewScientist March,4, 2020, https://www.newscientist.com/article/mg24532724-700-we-were-warned-so-whycouldnt-we-prevent-the-coronavirus-outbreak/\#ixzz6Nr2B2yof, accessed on Jan 9, 2021.

Evans, Malcolm., "UN Subcommittee on Prevention of Torture, (SPT)", April 7, 2020, https://www.coe.int/en/web/portal/-/international-day-in-support-of-victims-of-torturedetainees-need-protection-from-covid-19, accessed on Jan 2, 2021.

Poptsova, Maria., "Market Analysis- Clinical Microbiology 2020, Global Market Insights", Archives of Clinical Microbiology, https://www.acmicrob.com/microbiology/marketanalysis-clinical-microbiology-2020.php?aid=25052, accessed Jan 10, 2021. 
Akter, Marufa ., "Conceptualizing environmental governance on the GBM basin", Journal of the Global South, vol. 3, No. 1, December 2016. https://link.springer.com/article/10.1186/s40728-015-0025-7, accessed on Jan. 6,2021

Kavanagh, Mathew M., "Transparency and Testing Work Better Than Coercion in Coronavirus Battle", Foreign Policy, March 16, 2020, https://foreignpolicy.com/2020/03/16/coronavirus-what-works-transparency-testingcoercion/, accessed Jan 6, 2021.

McClain, Charles., "Of Medicine, Race, and American Law: The Bubonic Plague Outbreak of 1900." Law \& Social Inquiry, vol. 13, no. 3, 1988, pp. 447-513. www.jstor.org/stable/828412. Accessed Jan.16, 2021

Rull, Monica., Kickbusch, Ilona ., Lauer, Helen., "Policy Debate on International Responses to Global Epidemics: Ebola and Beyond", International Development Policy, December 3, 2015, http://journals.openedition.org/poldev/2178,10 May 29, 2020.

Rull, Monica., 'The Ebola Wake-up call:The System's failings in Responding to Outbreaks' International Development Policy , December 3, 2015, http://journals.openedition.org/poldev/2178, May 29, 2020.

National Disaster Management Division, "Disaster Management in India" Ministry of Home Affairs, Government of India, June 28, 2004

Alkire, Sabina., Robles,Gisela., "Global Multidiemsional Poverty Index 2017”, Oxford Poverty and Human Development Initiative, 2017 , https://ophi.org.uk/global-multidimensionalpoverty-index-2017/ accessed on Jan 7, 2021.

Zweifel, Peter., Breyer, Friedrich., Kifmann, Mathias., Health Economics,2nd Edition, (original edition OUP 1997), Springer, London, 2009.

Kotecha, Ronak., "Coronavirus Outbreak: India stares at strained ties with UAE as Abu Dhabi seeks to review labour relations with countries reluctant to take back expats", First Post, April 14, 2020, https://www.firstpost.com/india/coronavirus-outbreak-india-stares-atstrained-ties-with-uae-as-abu-dhabi-seeks-to-review-labour-relations-with-countriesreluctant-to-take-back-expats-8257541.html, accessed on Jan 3, 2021.

South Asia Co-operative Environment Programme, "South Asia's Biodiversity: Status, Trend and Challenges", SACEP, December 2016, http://www.sacep.org/pdf/newpublication/South-Asia-Biodiversity-Status-Trend-and-Challenges.pdf accessed on Jan 5, 2021.

Kafle, S.K., "Disaster Risk Management Systems in South Asia: Natural Hazards, Vulnerability, Disaster Risk and Legislative and Institutional Frameworks". J Geogr Nat Disast 7: 207.2017,p.5

Sunil, Rahar., "Report, Covid norms go for a toss during political gatherings in Baroda", Hindustan Times, Oct.25,2020, https://www.hindustantimes.com/cities/covid-norms-gofor-a-toss-during-political-gatherings-in-baroda/story-

TwqApRpKH7N5lrWf4yHubK.html, accessed on jan.3, 2021.

'Indian expats in UAE frustrated over government's repatriation plans', The Deccan Chronicle, May 7, 2020, https://www.deccanchronicle.com/world/middle-east/070520/indian-expatsin-uae-frustrated-over-governments-repatriation-plans.html, accessed on Jan. 2. 2021.

National Disaster Management Authority, "The Disaster Management Act 2005", Legislative Department, Government of India, http://legislative.gov.in/sites/default/files/A200553.pdf, accessed on Jan 6, 2021

Bhardwaj, Yogesh \& Sharma, Saurabh., "In Vrindavan, A Home for Widows Prepares To 
Protect Its Elderly From COVID-19" Health-Check in,” https://www.health-check.in/invrindavan-a-home-for-widows-prepares-to-protect-its-elderly-from-covid-19/4, April, 2020, accessed on 4 April, 2021.

Raman, Mini \& Talukdar, Angelina., "No Entitlement For claiming Force Majeure Relief during Covid-19”, Lexorbis ,https://www.lexorbis.com/no-entitlement-for-claiming-forcemajeure-relief-during-covid-19/) July 31,2020, accessed on Jan 10,2021.

Maron, Dina Fine, "Wet markets" https://www.nationalgeographic.com/ animals/2020/04/coronavirus-linked-to-chinese-wet-markets/ accessed on Jan 6, 12021.

The Epidemic Disease Act (EDA), 1897. https://www.indiacode.nic.in/bitstream/ 123456789/2326/1/ A1897_03.pdf, accessed on Sept.30, 2020.

The ILO Report "The International Labour Standards (ILS) and Covid-19", International Labour Organization,https://www.ilo.org/wcmsp5/groups/public/---ed_norm/--normes/documents/genericdocument/wcms_739937.pdf, accessed on Jan 6, 2021.

UN Women, Press release, "UN Women raises awareness of the shadow pandemic of violence against women during COVID-19", UN Women, available at https://www.unwomen.org/en/news/stories/ 2020/5/press-release-the-shadow-pandemicof-violence-against-women-during-covid-19, May 27, 2020.

UNESCO, "Mortality Risk Index", http://www.unesco.org/new/fileadmin/ MULTIMEDIA/HQ/ SC/temp/wwap_pdf/Mortality_Risk_Index.pdf, accessed on Jan 6, 2021.

World Bank, "South Asia Water Initiative" Annual Report from the World Bank to Trust Fund Donors,July 2014 to June 2015, Washington, D.C., 2015 , https://www.worldbank.org/en/ programs/sawi . accessed Jan 3, 2021.

World Bank, "Global Economic Prospects 2020”, World Bank Group, Washington DC, June 8, 2020, available at https://www.worldbank.org/en/news/press-release/2020/06/08/covid19-to-plunge-global-economy-into-worst-recession-since-world-war-ii accessed on Jan 3, 2021

WHO, 'mythbusters' available at https://www.who.int/emergencies/diseases/novelcoronavirus-2019/advice-for-public.accessed on April 1,2021.

Parmet, W.E., "Quarantining the law of quarantine: why quarantine law does not reflect contemporary constitutional law”. Wake Forest J Law Policy, Vol.9, 2018, pp. 1-33. 
Pandemic and the Emerging Threshold of Disaster Law in South Asia 